\title{
Range Extensions of 35 Bryophyte Species in the Black Spruce- Feather Moss Forest of Western Quebec, Canada
}

\author{
Marion Barbé ${ }^{1,4}$, Louis Dubois ${ }^{2}$, Jean Faubert $^{3}$, Martin Lavoie $^{2}$, Yves Bergeron ${ }^{1}$, and Nicole \\ J. FENTON ${ }^{1}$
}

${ }^{1}$ Université du Québec en Abitibi-Témiscamingue, Institut de recherche sur les forêts, 445, boul. de l'Université, Rouyn-Noranda, Quebec J9X 4E5 Canada

${ }^{2}$ Université Laval, Département de géographie, 2405, rue de la Terrasse, Québec, Quebec G1V 0A6 Canada

${ }^{3}$ Société québécoise de bryologie, 47, $4{ }^{\mathrm{ème}}$ Rang Est, Saint-Valérien-de-Rimouski, Quebec G0L 4E0 Canada

${ }^{4}$ Corresponding author: marion.barbe@uqat.ca

Barbé, Marion, Louis Dubois, Jean Faubert, Martin Lavoie, Yves Bergeron, and Nicole J. Fenton. 2017. Range extensions of 35 bryophyte species in the Black Spruce-feather moss forest of western Quebec, Canada. Canadian Field-Naturalist 131(3): 258-269. https://doi.org/10.22621/cfn.v131i3.1901

\begin{abstract}
Although the North American bryophyte flora are relatively well known, bryophytes of the Black Spruce-feather moss forest in the Nord-du-Québec administrative region, especially its southern portion $\left(49-51^{\circ} \mathrm{N}, 74-79^{\circ} \mathrm{W}\right)$, remain under-sampled. Here, we report 169 bryophyte taxa for this region, of which 35 (14 true mosses, 20 liverworts, one sphagnum) represent noteworthy records, including 20 taxa new for the region. These new occurrences close several gaps in distribution in the study area and, more broadly, in the boreal Black Spruce (Picea mariana) forest of adjacent Ontario. Microhabitat preferences of the species are also documented. This work represents a substantial contribution to knowledge of the bryophyte flora, which will help refine protection priority ranks of species of Quebec and Labrador.
\end{abstract}

Key Words: Boreal forest; bryoflora; bryo-geography; liverwort; true moss; sphagna; northern Quebec

Malgré une bonne connaissance globale de la bryoflore nord-américaine, la pessière noire à mousses de certaines régions telles que le Nord-du-Québec et notamment sa partie méridionale $\left(49-51^{\circ} \mathrm{N}, 74-79^{\circ} \mathrm{W}\right)$ demeure sous-échantillonnée. Nous rapportons 169 taxons bryophytiques dans cette région, dont 35 (14 mousses, 20 hépatiques et une sphaigne) représentent des ajouts substantiels à la flore, incluant même 20 nouveaux taxons pour le territoire considéré. Ces récoltes permettent de relier les aires de répartition jusque-là disjointes de plusieurs taxons en pessière noire à mousses au Québec, mais aussi dans la province jouxtante de l'Ontario. Les préférences des espèces en termes de microhabitats sont aussi décrites. Ce travail contribue à améliorer les connaissances sur la bryoflore et permettra de redéfinir les rangs de priorité pour la conservation des espèces au Québec et Labrador.

Mots-clés: aire de répartition; bryoflore; forêt boréale; hépatiques; mousses; sphaignes; Nord-du-Québec

\section{Introduction}

Bryophytes (liverworts, true mosses, and sphagna), along with lichens, dominate the coniferous boreal forest in terms of biomass, species richness (Turetsky et al. 2012), and net primary productivity (Bisbee et al. 2001; Proctor 2011). They form a continuous carpet several centimetres thick and inhabit a variety of microhabitats (Dynesius and Hylander 2007). Bryophytes represent $25 \%$ of the plant diversity of Quebec (Faubert et al. 2010). In 2016, the database of the bryophytes of Quebec-Labrador listed 231 species of liverworts, 582 species of mosses, and 62 species of Sphagnum (Faubert et al. 2014+). However, the distributional ranges of some species are only partly defined, and the bryophyte flora is unknown in certain areas (Faubert and Gagnon 2013).

This is the case for the administrative region of Abitibi-Témiscamingue and the adjacent southern portion of the Nord-du-Québec administrative region, which have been neglected in terms of bryophyte sampling compared with other regions. Understanding the frequency and distribution of species is of primary importance in establishing conservation plans and in implementing resource management practices in these regions, where boreal forests are disturbed both by nat- ral wildfires and anthropogenic exploitation (forest harvest, mining, hydroelectric development). These cumulative disturbances of the landscape threaten species that are ill-adapted to anthropogenic environments, including many bryophytes (Fenton and Frego 2005; Hylander et al. 2005; Caners et al. 2013).

Since the publication of the Catalogue des bryophytes du Québec et du Labrador (Faubert 2007), the number of bryophyte species documented in Quebec and Labrador has continued to grow (Gauthier 2011; Moisan and Pellerin 2011; Faubert et al. 2012; Faubert and Gagnon 2013). New occurrences are continuously being compiled in the online database of the bryophytes of Quebec-Labrador (Faubert et al. 2014+), contributing to continuous updating of the bryophyte flora (Faubert 2012-2014). The current study contributes to our understanding of bryophyte distributional ranges at the scale of the boreal Black Spruce (Picea mariana (Miller) Britton, Sterns \& Poggenburgh) forest of Quebec-Labrador. We describe the bryophyte community of this forest bioclimatic domain, including microhabitat preferences, which may permit better forest development practices and bryophyte conservation. 


\section{Study Area}

The study area covers $73197 \mathrm{~km}^{2}\left(48^{\circ} 83^{\prime} \mathrm{N}\right.$ to $50^{\circ} 71^{\prime} \mathrm{N}$ and $74^{\circ} 50^{\prime} \mathrm{W}$ to $79^{\circ} 69^{\prime} \mathrm{W}$ ) in the southern portion of the Nord-du-Québec administrative region of western Quebec (Figure 1). After the retreat of the Laurentide Ice Sheet, the area was covered by the proglacial lakes Barlow and Ojibway, which existed 11500 and 7900 radio carbon years before present, respectively (Vincent and Hardy 1977). Sedimentation in the lakes generated a layer of clay 10-60 m thick that forms the soils of the "clay belt" of northeastern Ontario and northwestern Quebec. There is little topographic variation in the region, with elevations ranging from 200 to $300 \mathrm{~m}$ above sea level.
The study area is located in the Black Spruce-feather moss forest bioclimatic domain that extends over 154 $184 \mathrm{~km}^{2}$ in Quebec (Grondin 1996). Forest stands are dominated by Black Spruce, Jack Pine (Pinus banksiana Lambert), Trembling Aspen (Populus tremuloides Michaux), Balsam Fir (Abies balsamea (L.) Miller), and Paper Birch (Betula papyrifera Marshall). The understorey is dominated by ericaceous shrubs on a ground cover of bryophytes (Saucier et al. 2009). The natural dynamics of these forests are driven primarily by standreplacing wildfires. The fire cycle has been estimated at 398 years (Bergeron et al. 2004), and the average age of the forest is over 150 years. Average annual temperature and precipitation (1981-2010) are $1^{\circ} \mathrm{C}$ and $928 \mathrm{~mm}$,

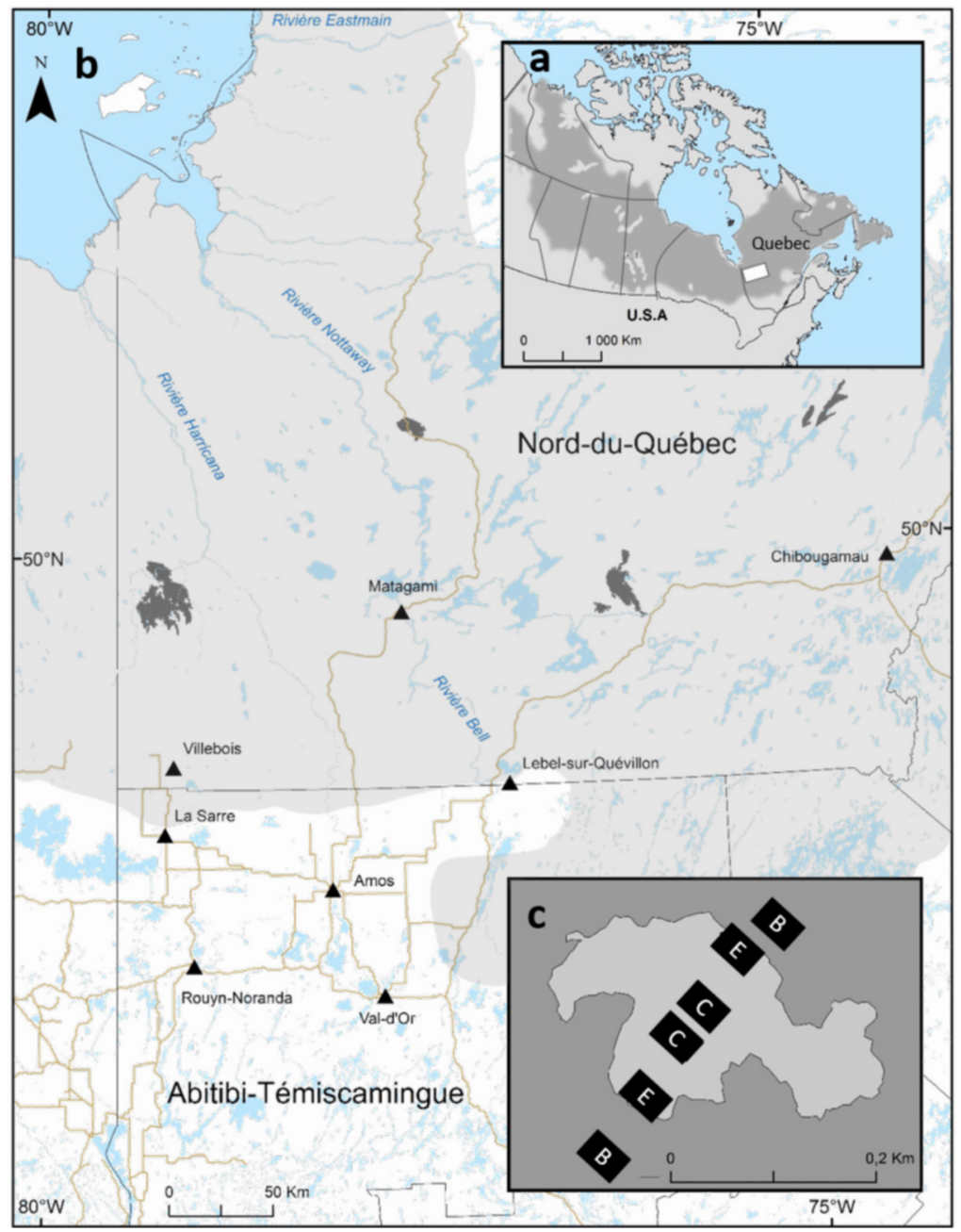

FIGURE 1. a. Location of the study area (white square) in the Nord-du-Québec administrative region of western Quebec, Canada, within the boreal Black Spruce (Picea mariana) forest bioclimatic domain (dark grey). b. The six wildfires sampled (dark grey shapes) in Black Spruce forest bioclimatic domain (light gray zone; adapted from Payette and Bouchard 2001). Triangles represent main cities. c. Black rectangles represent sample plots of $50 \mathrm{~m}^{2}$ located along a transect crossing the residual patch (light grey) from burned area (B) to edge (E) and core (C). 
respectively (Environment Canada 2017). The region is characterized by long winters, with $313 \mathrm{~cm}$ of snowfall annually, and a short growing season of 140-160 days.

\section{Methods}

\section{Bryophyte Sampling}

Bryophytes were sampled within the footprints of six natural wildfires (Figure 1b) varying in age, size, and origin and used for a study on post-fire residual forest patches (Barbé et al. 2016, 2017). Within each wildfire footprint, we identified five residual patches (unburned forest areas) and three burned areas for a total of 30 residual patches aged 36-3400 years (time since last wildfire) and 18 burned matrices aged 10-44 years (time since last wildfire). The age of the patches was estimated by coring 10 dominant trees; if the 10 dominant trees were approaching their maximum lifespan ( $>180$ years old for Black Spruce; Simard et al. 2007) the age of the patch was determined by ${ }^{14} \mathrm{C}$ dating of charcoal particles extracted from the mineral soil. Age of burned areas corresponds to time since the last fire determined from Société de protection des forêts contre le feu digital maps (SOPFEU 2011). All residual patches were chosen based on the following criteria: Black Spruce dominance, accessibility $(<600 \mathrm{~m}$ from the logging road), flat topography, and no complete submergence of the soil except in local depressions (waterholes). No bogs or fens were sampled, but post-fire residual patches located in paludified (i.e., natural succession to peatland; Crawford et al. 2003) Black Spruce forests were included. Consequently, we sampled sites encompassing the range of natural Black Spruce forest succession: from recently burned to paludified areas. Patches varied in size $(0.05-11.1 \mathrm{ha})$ and forest structure (e.g., 7.4-109 $\mathrm{m}^{3} /$ ha of coarse woody debris). More details about the characteristics of the patches are presented in Barbé et al. (2017).

Rectangular plots $\left(50 \mathrm{~m}^{2}\right)$ were used to sample the bryophyte communities in each residual patch and burned area. At each location, a north-south linear transect was established that included the burned zone, edge, and core positions (Figure 1c). In patches smaller than $1 \mathrm{ha}$, five plots were placed along the transect: two in the surrounding burned zone, two straddling each edge of the patch, and one in the core. In patches over $1 \mathrm{ha}$, a second core plot was added. Plots were 10-200 m apart. In each wildfire footprint, three additional $50-\mathrm{m}^{2}$ plots of burned area were placed $200-850 \mathrm{~m}$ from residual patches. Size, number, orientation, and placement of sampling plots were chosen to include all microhabitats at each site, from more humid and cold microhabitats found at the northern edge and in residual patch cores, to warmer and drier microhabitats found at the southern edge and in burned areas. In total, the bryophyte community was sampled over $9300 \mathrm{~m}^{2}: 108$ plots in 30 residual patches (48 cores and 60 edges) and 78 plots in burned areas $(2 \times 30$ residual patches plus $3 \times 6$ wildfires). The four corners of each plot were geo- located using a handheld global positioning system receiver (Garmin GPSmap 62, Olathe, Kansas, USA).

In each $50-\mathrm{m}^{2}$ plot, the bryophyte community was sampled using a modified form of "floristic habitat sampling" (Newmaster et al. 2005), which consists of sampling all the bryophytes present in all microhabitats (e.g., coarse woody debris, tree bases, peat mounds, water holes). This method was used to ensure that all small non-visible species were captured. Vouchers of all specimens are stored at the Université du Québec en Abitibi-Témiscamingue (Rouyn-Noranda, Canada). Nomenclature follows Faubert et al. (2014+) except for Sphagnum subtile (Russ.) Warnst. (Flora of North America Editorial Committee 2007).

All samples were dried and later identified to species level using a stereomicroscope and a compound light microscope following the specimen preparation and identification method described in Faubert (2012). Damaged, senescent, or immature specimens were identified only to genus level. The microhabitat in which each species was found was qualitatively compared with data from Flore des Bryophytes du Québec-Labrador (Faubert 2012-2014; herein shortened as "Flora") to determine whether a species was specific to certain microhabitats in the study area.

\section{Distribution Maps}

Provincial distribution maps were generated for species found in this study whose ranges differed from those previously known in Quebec. New occurrences were compared with those detailed in the open-access BRYOQUEL participative online database of the bryophytes of Quebec-Labrador (Faubert et al. 2014+). New occurrences were also compared with documented occurrences from the neighbouring province of Ontario (Ireland and Ley 1992; Ley and Crowe 1999; CNALH 2017). Maps were generated using the geographic information system, ArcGis 10.3.1 (Environmental Systems Research Institute [ESRI], Redlands, California, USA). Original map layers were from the GéoIndex+ platform of the Geographic and Statistic Information Centre (GéoStat Centre) of the Université Laval created with data from Statistics Canada, geographic division, DMTI Spatial Inc. (Richmond Hill, Ontario, Canada), and ESRI. The projection used for all maps was NAD83 CSRS MTM 10.

\section{Data Analyses}

Provincial occurrences, extracted from Faubert $e t$ al. (2014+), are "previously documented occurrences" and were classified into four categories: rare $(<5 \mathrm{oc}-$ currences), infrequent (5-10), uncommon (11-30), and common (>30; Table 1). There was no minimum distance between occurrences. The local occurrences from this study were treated as "new occurrences". Local occurrences refer to the record of one species in a residual patch or a burned area. Indeed, even though a species was found several times in the same residual patch or burned area (i.e., several records in the same $50-\mathrm{m}^{2}$ 
plot), only one occurrence was drawn on the map (one cross) to avoid overloading maps with superimposed crosses. Local occurrences followed the same categories as provincial ones but were based on the number of plots where the species was found: rare (recorded in $<5$ plots), infrequent (5-10 plots), uncommon (11-30 plots), and common ( $>30$ plots). Local occurrences were used to refine species occurrences in Quebec. For example, a species represented by 28 provincial occurrences plus 10 new local occurrences was updated from uncommon to common in Quebec. Each occurrence (provincial as well as local) was presented regardless of plot and site location. Species were grouped by their provincial and local occurrences: group 1: locally uncommon/infrequent species already recorded near the study area; group 2: provincially common to rare species only recorded sporadically near the study area; group 3: species that were new occurrences for the study area.

Microhabitats of species in the study area were compared with those documented in Flora (Faubert 20122014), which were compiled from an exhaustive list of preferential microhabitats found in the literature (Schuster 1966-1992; Crum and Anderson 1981; Ireland 1982) plus additional microhabitats from specimens collected in Quebec. Thus, we compared species' microhabitat preferences between boreal Black Spruce forest and habitats in the rest of the province and the species' Canadian distribution to identify differences in microhabitat preferences in the Black Spruce forest of western Quebec. Microhabitats were classified as humus (T: terricolous species living on soil and litter), peat (B: species living among sphagna or on exposed peat in paludified areas), dead wood (DW: facultative or obligate epixylics), epiphyte (EP: epiphytic or corticolous species on living trees and shrubs), and rock (R: saxicolous species).

\section{Results}

\section{Bryophyte Community and Species Distribution}

Bryophytes were sampled in 11036 microhabitats, each containing on average four species (range 0-20) for a total of 169 species encountered (61 liverworts, 90 mosses, and 18 sphagna; Appendix S1). Locally, 118 species ( $70 \%$ of all species) were common (found in more than 30 plots); the remaining species occurred more sporadically over the sampling area.

Post-fire residual patches were dominated by the feather mosses, Hylocomium splendens (Hedw.) Schimp., Pleurozium schreberi (Willd. ex Brid.) Mitt., and Ptilium crista-castrensis (Hedw.) De Not., with frequent occurrences of the acrocarp species, Dicranum fuscescens Turner and Polytrichum commune Hedw. var. commune, and of the liverworts, Lophozia ventricosa (Dicks.) Dumort, Ptilidium ciliare (L.) Hampe, and Ptilidium pulcherrimum (Weber) Hampe. The wettest sites also supported Aulacomnium palustre (Hedw.) Schwägr., Sanionia uncinata (Hedw.) Loeske, and Warnstorfia
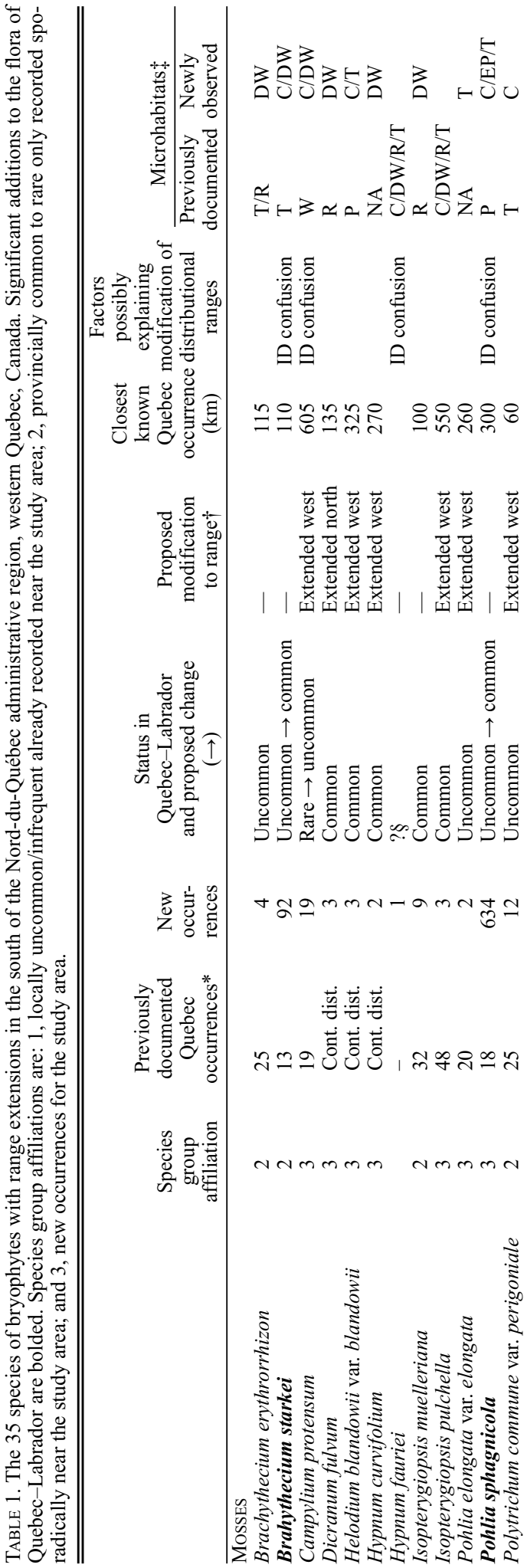


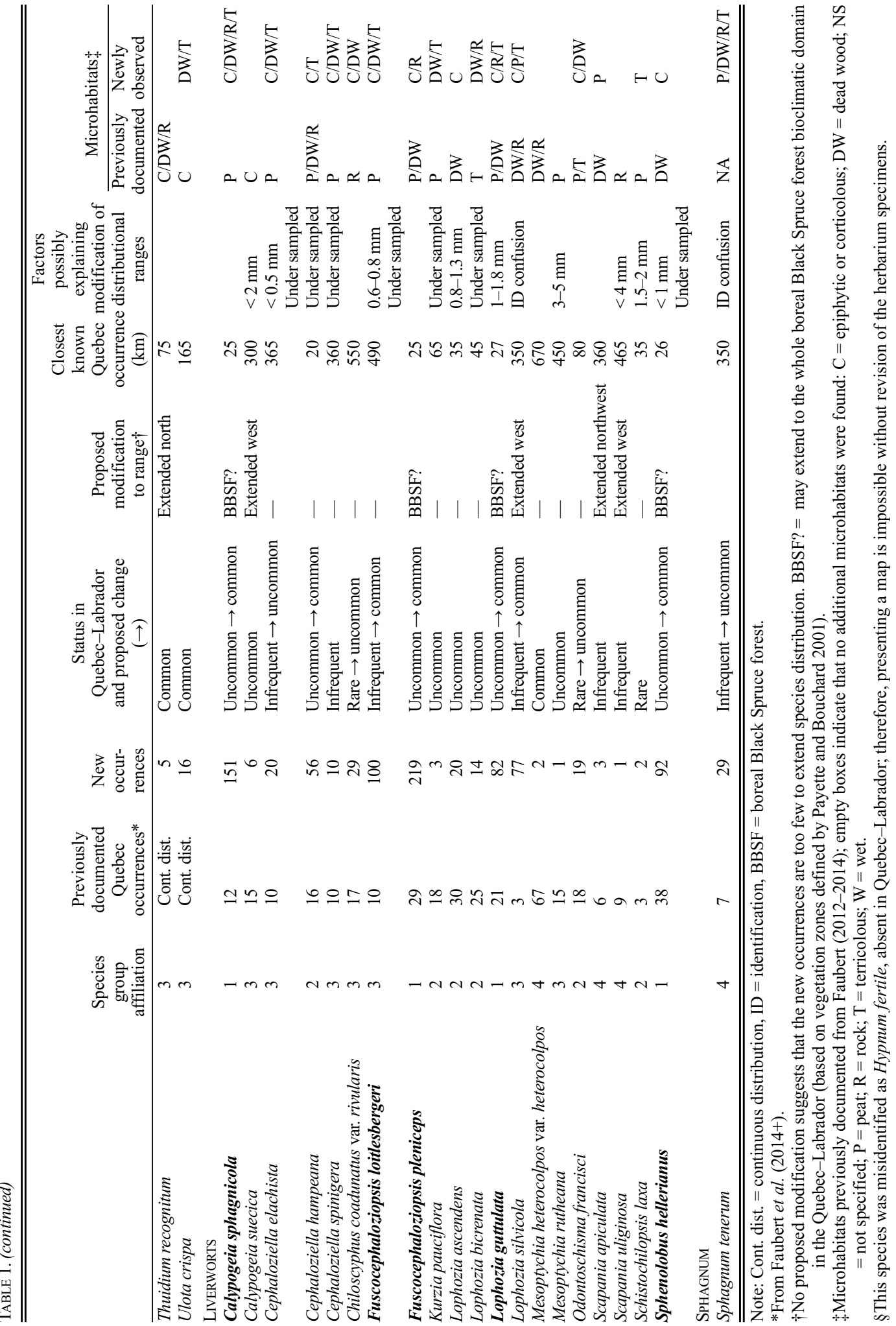




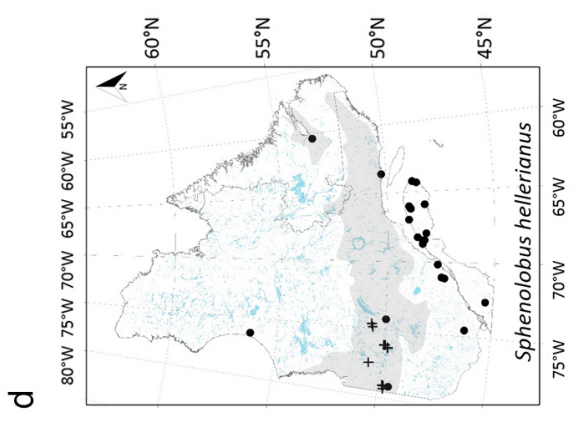

के
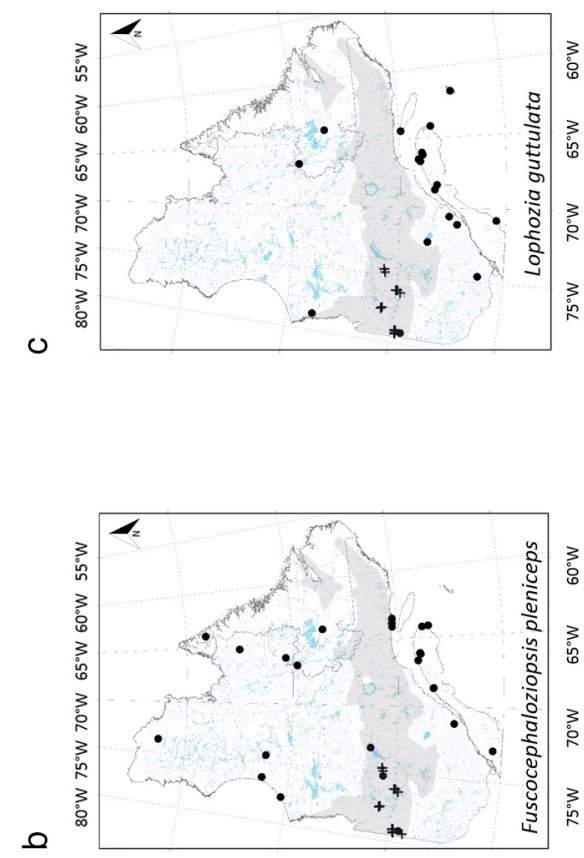

fluitans (Hedw.) Loeske, whereas Ceratodon purpureus (Hedw.) Brid., Polytrichum juniperinum Hedw., and Pohlia nutans (Hedw.) Lindb. were found mainly in burned areas, which were also the driest sites. In addition, deep mats of sphagna (Sphagnum capillifolium (Ehrh.) Hedw., Sphagnum fallax H. Klinggr., Sphagnum magellanicum Brid.) were found, as many of the sites sampled were undergoing paludification (Fenton et al. 2005). Some of the species described as common in the coniferous boreal forests of Quebec in Faubert (2012-2014) were under-represented ( $\leq 15$ occurrences) in our samples (e.g., Barbilophozia hatcheri (A. Evans) Loeske, Bryum capillare Hedw., Tomenthypnum nitens (Hedw.) Loeske).

In addition to these locally common species, 35 species (14 true mosses, 20 liverworts, and one sphagnum) represent noteworthy records (Table 1). Of these, four species (group 1) were locally uncommon or infrequent, but were expected to be found because they have already been recorded $25 \mathrm{~km}$ from the study area in Quebec and 50-150 km from the study area in Ontario: Calypogeia sphagnicola (Arnell \& J. Perss.) Warnst. \& Loeske, Fuscocephaloziopsis pleniceps (Austin) Váňa \& L. Söderstr., Lophozia guttulata (Lindb. \& Arnell) A. Evans, and Sphenolobus hellerianus (Nees ex Lindenb.) Steph. (Figure 2). Ten other species (group 2), including four true mosses (Brachythecium erythrorrhizon Schimp., B. starkei, (Brid.) Schimp., Isopterygiopsis muelleriana (Schimp.) Z. Iwats., Polytrichum commune Hedw. var. perigoniale (Michx.) Hampe and six liverworts (Cephaloziella hampeana (Nees) Schiffn. ex Loeske, Kurzia pauciflora (Dicks.) Grolle, Lophozia ascendens (Warnst.) R.M. Schust., L. bicrenata (Schmidel) Dumort., Odontoschisma francisci (Hook.) L. Söderstr. \& Váňa, Schistochylopsis laxa (Lindb.) Konstant.) were provincially common to rare, but had been recorded only sporadically near the study area (one to three occurrences 20-115 km; Figure 3). Some of these moss species are found west of the study area, in Ontario (i.e., Brachythecium erythrorrhizon, B. starkei, Polytrichum commune var. perigoniale), where they have already been recorded 50-200 km from the provincial border (Ireland and Ley 1992; Ley and Crowe 1999; CNALH 2017).

Finally, 20 species (group 3) are new occurrences for the study area, with range extensions from $75 \mathrm{~km}$ to more than $670 \mathrm{~km}$ in Quebec-Labrador. These include nine true mosses (Campylium protensum (Brid.) Kindb., Dicranum fulvum Hook., Helodium blandowii (F. Weber \& D. Mohr) Warnst. var. blandowii, Hypnum curvifolium Hedw., Isopterygiopsis pulchella (Hedw.) Z. Iwats., Pohlia elongata Hedw. var. elongata, P. sphagnicola (Bruch \& Schimp.) Broth., Thuidium recognitum (Hedw.) Lindb., Ulota crispa (Hedw.) Brid.), 10 liverworts (Calypogeia suecica (Arnell \& J. Perss.) Müll. Frib., Cephaloziella elachista (J.B. Jack) Schiffn., C. spinigera (Lindb.) Jörg., Chiloscyphus coadunatus (Sw.) R.M. Schust. \& J.J. Engel var. rivularis (Raddi) 


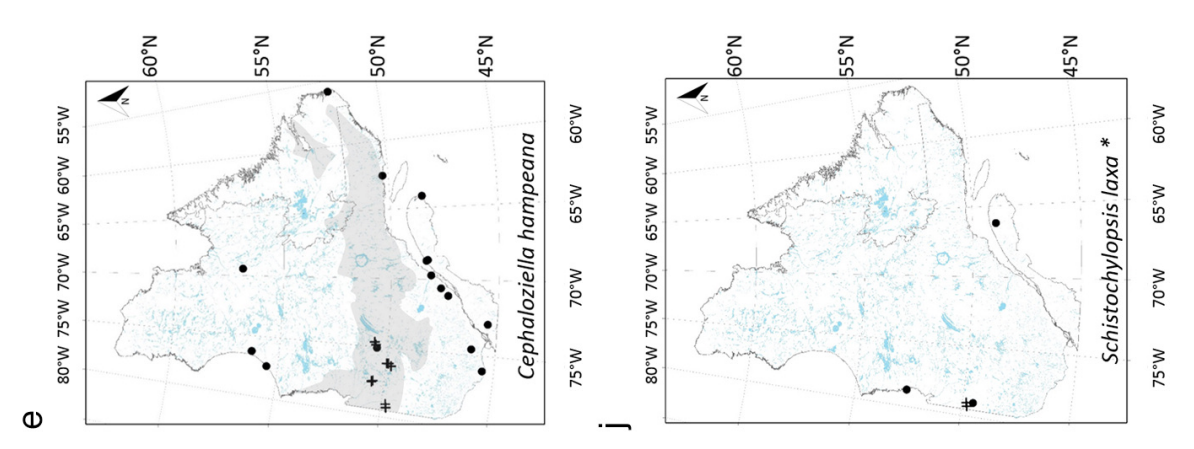

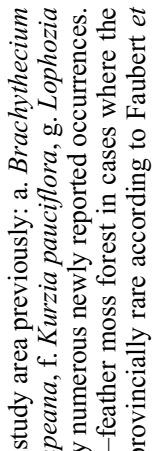
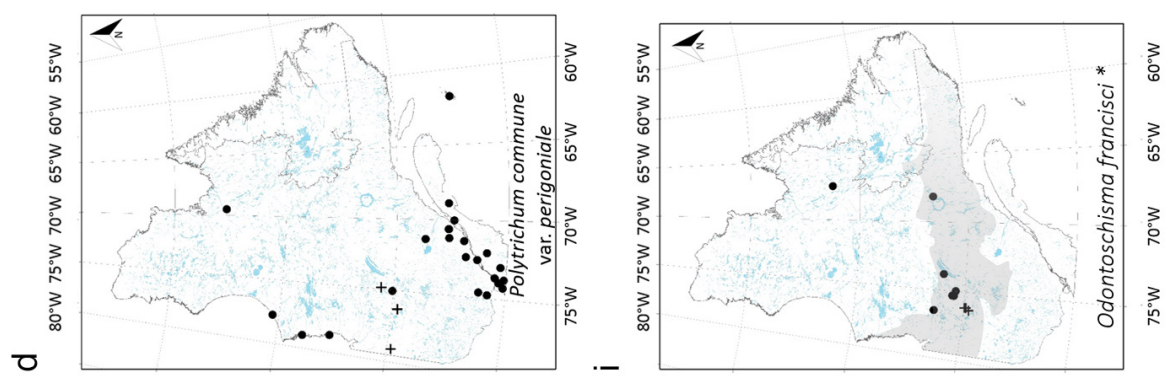

옹을

豞语

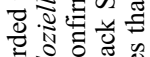

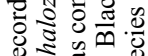

ई है कू

氜

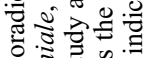

की

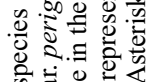

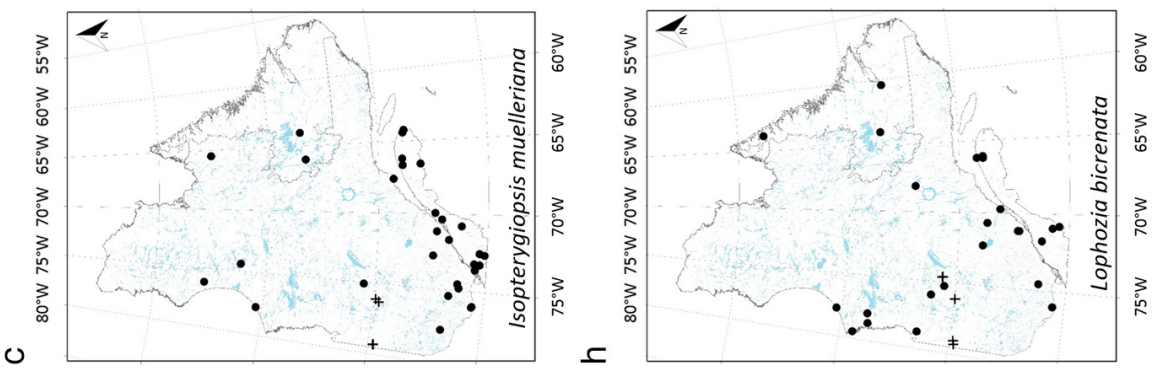

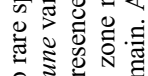

욯ㅎㅎㅎㅎㅇ

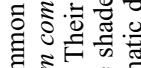

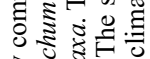

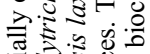

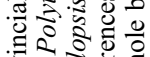

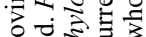

कㅇํำ
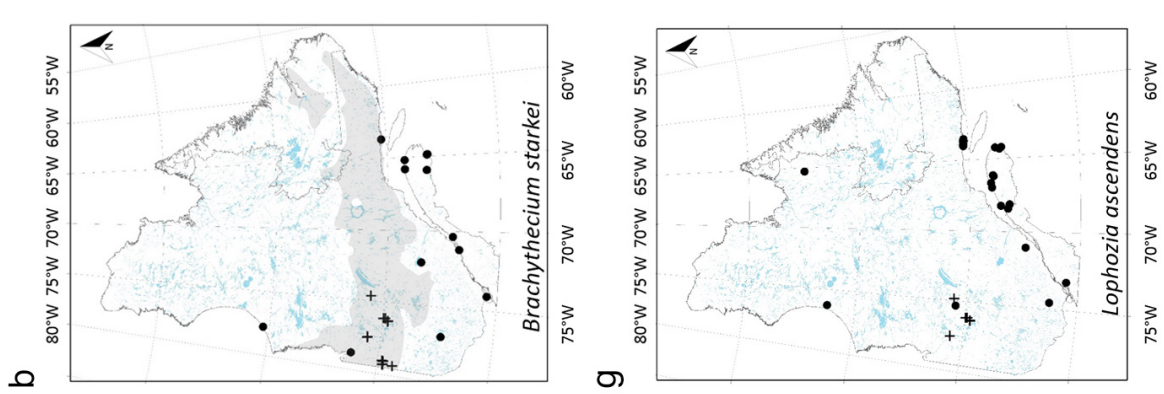

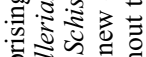

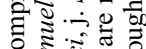

0 의

บ.

퓽.

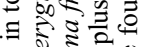

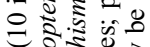

v

获

क力

की
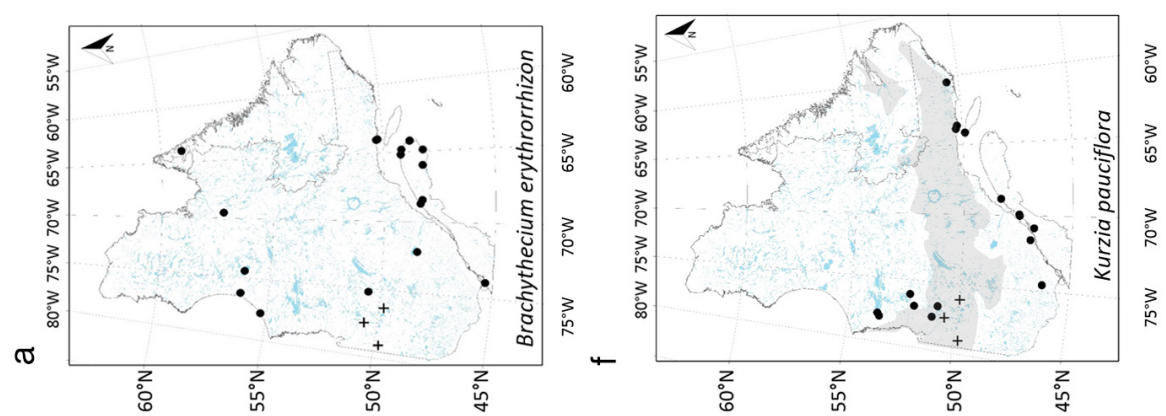

क्ष

पㄴ.

荡

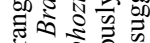

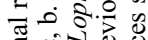

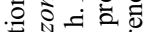

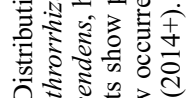

m

窇 
Frisvoll, Elvebakk, Flatberg \& Okland, Fuscocephaloziopsis loitlesbergeri (Schiffn.) Váňa \& L. Söderstr., Lophozia silvicola $\mathrm{H}$. Buch, Mesoptychia heterocolpos (Thed. ex Hartm.) L. Söderstr. \& Váña var. heterocolpos, Mesoptychia rutheana (Limpr.) L. Söderstr. \& Váňa, Scapania apiculata Spruce, S. uliginosa (Lindenb.) Dumort.), and one sphagnum (Sphagnum tenerum Sull. \& Lesq. ex Sull.; Figure 4). Considering occurrences from Ontario, we report a 50-200 km eastward extension of the distributional range of Helodium blandowii var. blandowii, Isopterigiopsis pulchella, Pohlia sphagnicola, and Thuidium recognitum (Ireland and Ley 1992; CNALH 2017).

Hypnum fauriei Cardot was sampled once in the study area. No map was produced for this species because its distribution in the province is unknown as a result of its recent separation from $H$. fertile Sendtn. (Faubert 2014).

\section{Bryophyte Microhabitat Preferences}

The microhabitat preferences of the 35 species discussed above were more diverse than reported previously in Flora (Faubert 2012-2014; Table 1). For example, two mosses (Pohlia sphagnicola and Calypogeia sphagnicola) and several liverworts were found in a greater variety of microhabitats than the exclusive peat microhabitat mentioned in Flora (Faubert 2012-2014). Eighteen species were recorded on tree or shrub bases in Black Spruce forest, especially Picea mariana and Rhododendron groenlandicum (Oeder) Kron \& Judd (Table 1), although they were not described as corticolous or epiphytic at the provincial scale. Half were associated with only one tree or shrub species, but multiple hosts were also identified for many bryophyte species (e.g., Pohlia sphagnicola, Brachythecium starkei, Cephaloziella elachista; data not shown). Similarly, numerous species not previously identified as epixylics in Flora (Faubert 2012-2014) were found on dead wood (Table 1; e.g., Brachythecium erythrorrhizon, Dicranum fulvum).

\section{Discussion}

Among the 169 bryophytes species identified, we have documented 20 new species for the study area and increased the understanding of the distributional range for 15 others. Our results suggest that these species may be more common in Quebec-Labrador and especially in the bioclimatic domain of the Black Spruce-feather moss forest, than previous occurrences indicate. We examine here the noteworthy occurrences within groups 1,2 , and 3 as identified above.

\section{Distributional Ranges Extended to the Entire Boreal Black Spruce Forest Bioclimatic Domain}

Even though already documented in the study area, we extended the known distribution of four species of liverwort (Calypogeia sphagnicola, Fuscocephaloziopsis pleniceps, Lophozia guttulata, and Sphenolobus hellerianus), with 82 to more than 200 new occurrences for these species. These occurrences, together with those already documented from eastern Quebec, suggest their continuous distributional ranges extend throughout the Black Spruce forest of Quebec-Labrador. Furthermore, the dispersed and numerous locations of these species indicate that they are common but under-sampled in the province. Further extension of their continuous distributional ranges to all of Quebec-Labrador may be possible, but more sampling is needed to determine their true distributions.

Our results also extend to the entire Black Spruce forest domain the known distributions of the liverworts Cephaloziella elachista, C. hampeana, C. spinigera, Chiloscyphus coadnatus var. rivularis, Fuscocephaloziopsis loitlesbergeri, Kurzia pauciflora, and Odontoschisma francisci, and of the true mosses Brachythecium starkei and Pohlia sphagnicola. However, some of them (Cephaloziella elachista, C. spinigera, Chiloscyphus coadnatus var. rivularis, F. loitlesbergeri, Lophozia silvicola, and $O$. francisci) have only rarely been recorded in eastern Quebec; further sampling is needed to confirm their presence across the province. In light of the 92 and 56 new occurrences of B. starkei and C. hampeana, respectively, as well as the 634 new occurrences of $P$. sphagnicola, the status of these species in the province should be changed from uncommon to common. Liverworts, especially Cephaloziellaceae and K. pauciflora, are minute $(<1 \mathrm{~mm}$ wide shoots) and especially difficult to detect, which has probably contributed to the underestimation of their frequency and distribution. Directed sampling efforts focusing on these taxa might help distinguish between a lack of sampling versus true rarity in other regions. The distributional ranges of the true mosses $B$. starkei and P. sphagnicola are unclear because of past misidentifications (Faubert 2012-2014). Indeed, in the past, the few and confusing diagnostic characters discriminating these species from others of the same genera have led to confusion between B. starkei and B. curtum (Lindb.) Limpr., $P$. sphagnicola and $P$. nutans, and between Sphagnum tenerum and $S$. capillifolium.

Lophozia bicrenata also needs attention. This uncommon and minute species, typical of disturbed landscapes, is present in dispersed locations across the entire province. It is possible that this species is found province-wide, but this possibility can only be addressed by additional sampling to discriminate between true rarity and under-collection.

\section{Distributional Ranges Extended to the North and West}

The few new reported occurrences of Dicranum fulvum and Thuidium recognitum (three and five, respectively) extend the provincial distribution of these species $135 \mathrm{~km}$ to the north and $75 \mathrm{~km}$ to the west, respectively. These species are common in the province, but have not been previously recorded in the study area. Helodium blandowii var. blandowii, Hypnum curvifolium, and Ulota crispa are also common. However, we do not suggest extension of their continuous distributions be- 

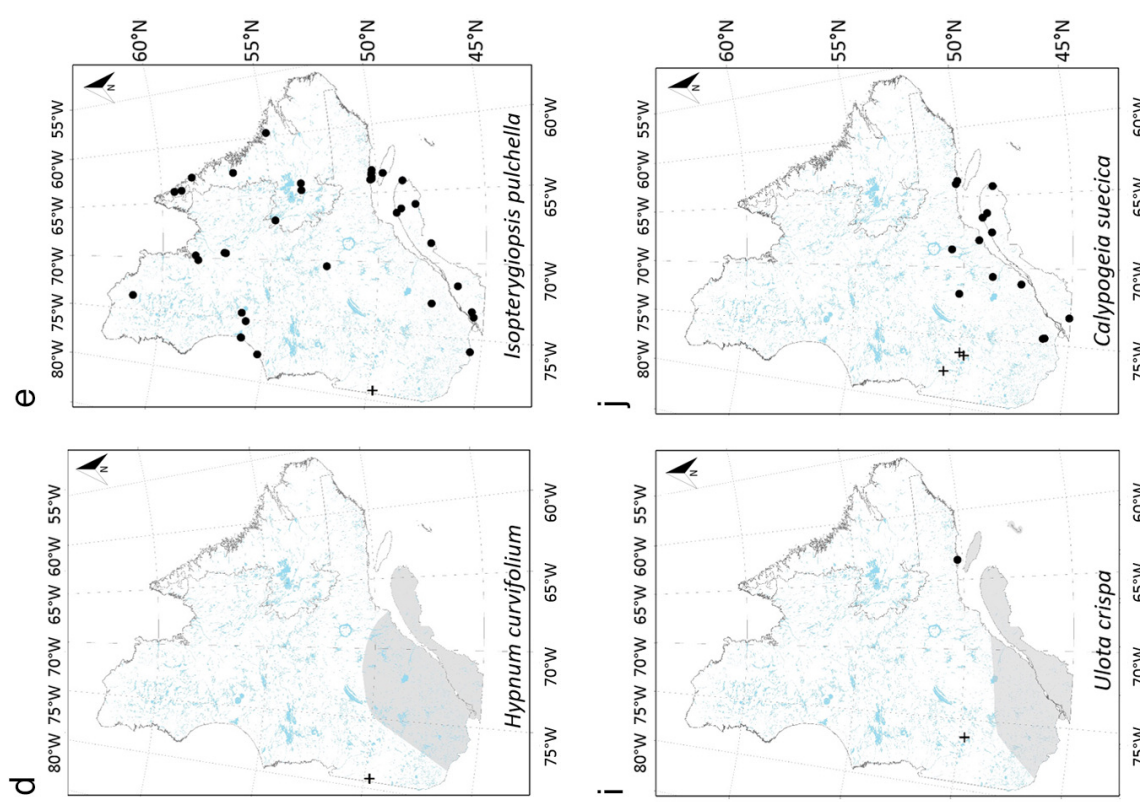

곤 운 品

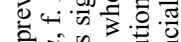

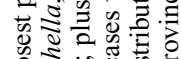

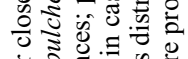
ज记

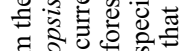

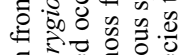

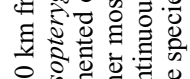

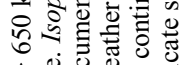

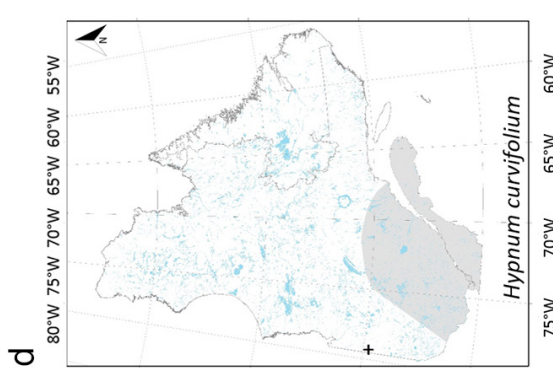

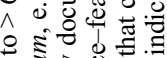
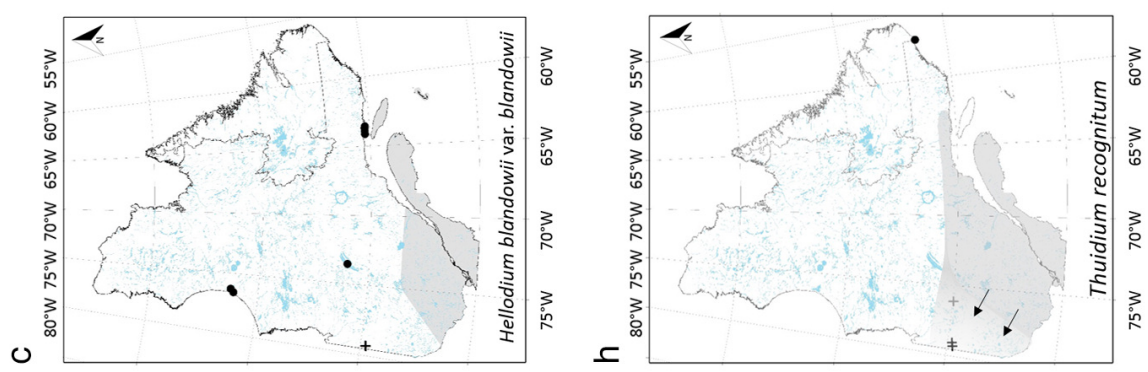

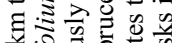

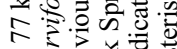

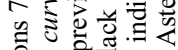

畜 总

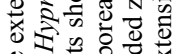

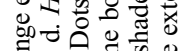

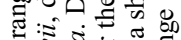

ปี :

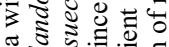

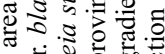

希宊

क:

웜

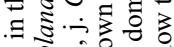

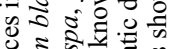

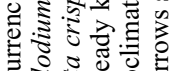

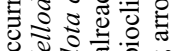

ช 85

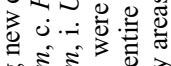

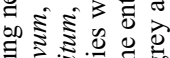
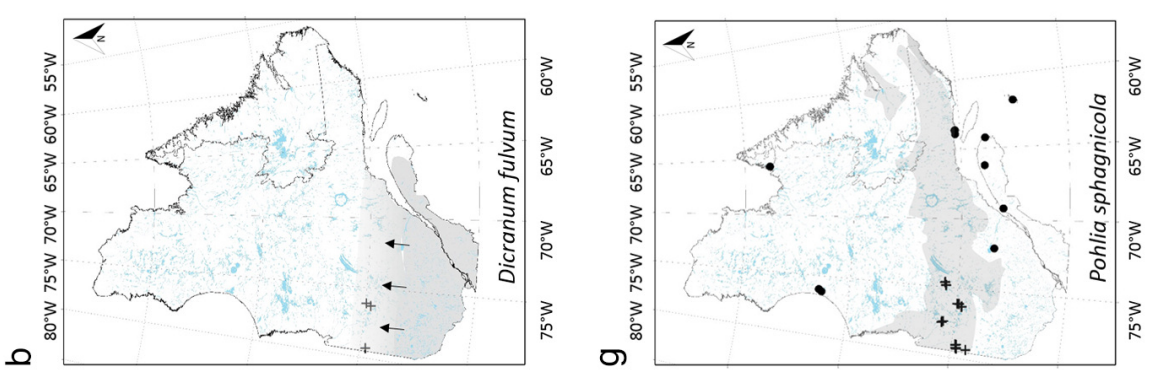

जड 50 \%

है इ

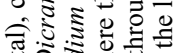

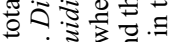

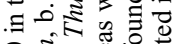

¿ิ

ก ฐ ฐ

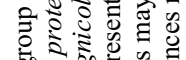

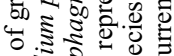

पे
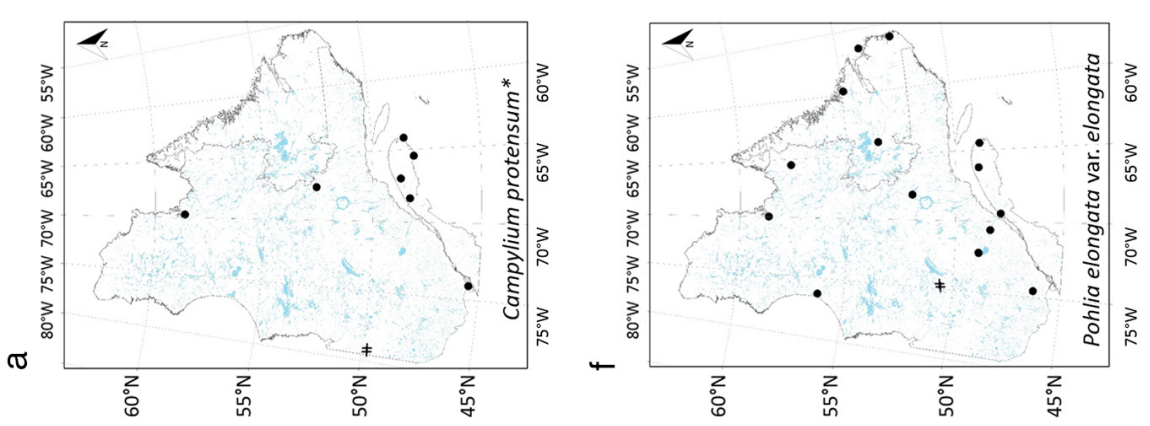

प्रे

क⿺辶一

品 on

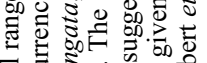

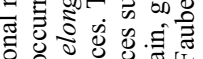

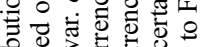

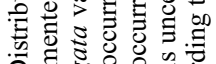

咅

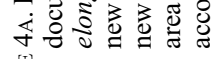




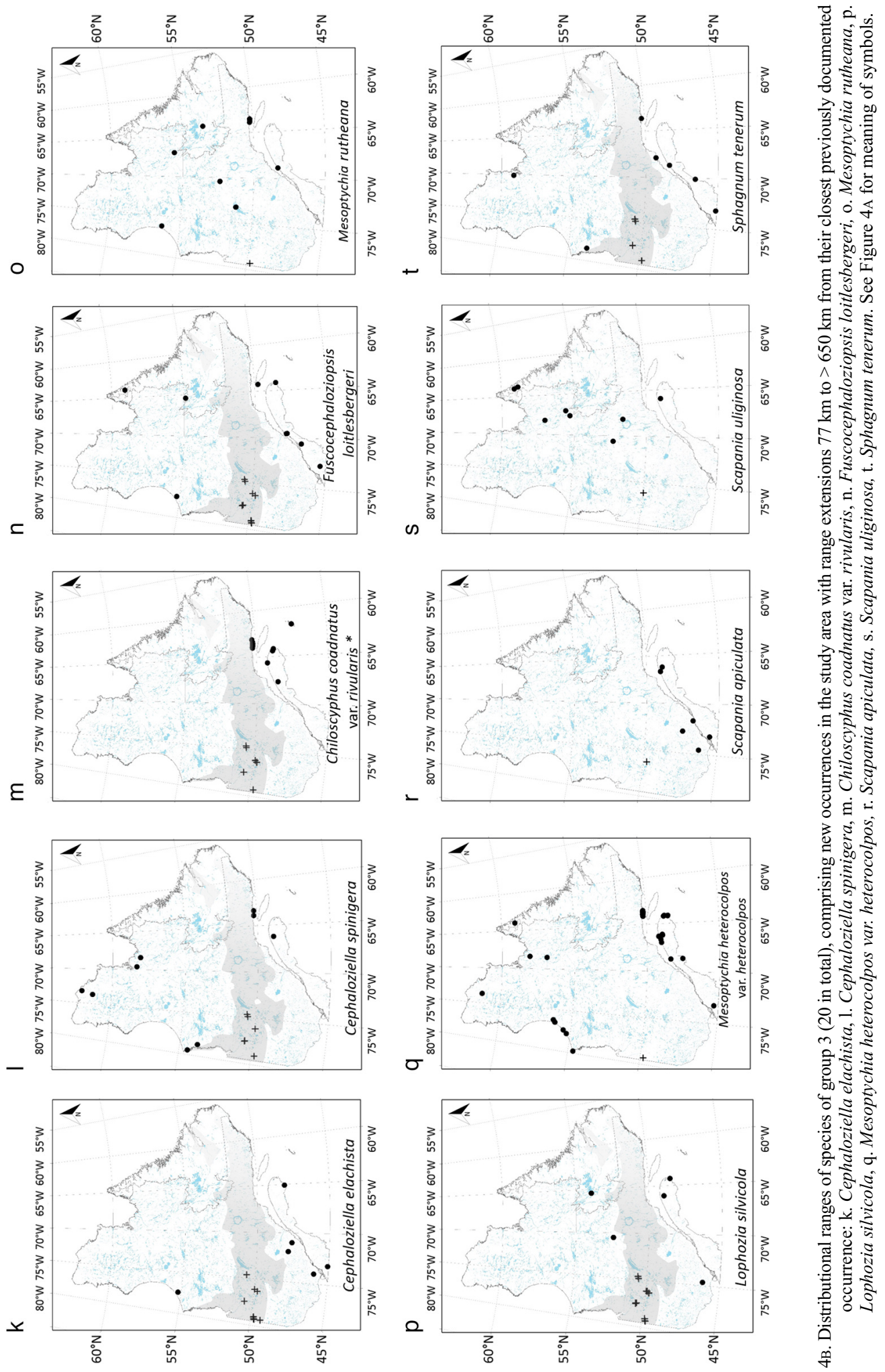


cause only one occurrence of each species was recorded in the study area, and the distance from the rest of their known Quebec range is substantial $(325,270$, and $165 \mathrm{~km}$, respectively).

Finally, the few occurrences (generally $<10$ ) of the remaining 14 species do not suggest a continuous distribution of those species, but rather their sporadic presence over the study area. The new occurrences of Brachythecium erythrorrhizon, Isopterygiopsis muelleriana, Polytrichum commune var. perigoniale, Lophozia ascendens, and L. bicrenata close gaps in their provincial distribution between southern and northern Quebec but also, in the case of B. erythrorrhizon and $P$. commune var. perigoniale, between eastern Quebec and Ontario. Furthermore, we document the presence of Campylium protensum, Isopterygiopsis pulchella, Pohlia elongata var. elongata, Calypogeia suecica, Mesoptychia rutheana, M. heterocolpos var. heterocolpos, Scapania apiculata, and S. uliginosa in the southern portion of Nord-du-Québec, 260-670 km west of their previously documented Quebec occurrences.

Our discoveries of the rare true mosses Campylium protensum and Hypnum fauriei and the rare liverworts Chiloscyphus coadnatus var. rivularis, Odontoschisma francisci, and Schistochylopsis laxa, confirm the importance of bryophyte sampling efforts in the neglected regions of Quebec-Labrador. However, some of the species described here may be misunderstood as a result of under-sampling or taxonomic confusion. Recent changes in species taxonomy have made herbarium specimens unreliable describers of species abundance until they can be re-examined and their identifications confirmed.

Finally, considering a larger geographic perspective, even though our findings represent significant distributional extensions within the province of Quebec, for some species the distance from the adjoining Ontario populations is less substantial $(50-200 \mathrm{~km}$, on average, from our study area). However, bryophyte distributions in Ontario are not as well or as recently documented as in Quebec (Faubert 2012-2014). Therefore, it is difficult to evaluate the exact distances between species occurrences. These species were found in eastern Ontario, in some localities of the Hudson Bay lowlands, and the Clay Belt region. The Clay Belt straddles Quebec and Ontario and its specific soil conditions may explain why the two provinces shared bryophyte assemblages.

\section{Conclusions and Implications for Management and Conservation}

This study suggests that numerous bryophytes may be more common than expected in Quebec-Labrador. We present a substantially revised and updated list of the bryoflora of the southern Nord-du-Québec administrative region. The updated ranges documented here can not only be used to redefine the protection priority ranks of these species, but may also aid in predicting the impacts of forest harvest and global climate changes. At the microhabitat level, our results indicate that some species had singular preferences in terms of habitat in the Black Spruce forest compared with other ecosystems across the province. Species found in our study occupied, in general, more diverse microhabitats and particularly more woody ones.

The southern portion of the Nord-du-Québec administrative region is considered by Quebec bryologists to be a "black hole" in terms of knowledge about the distribution of the bryophyte flora, reflecting the paucity of sampling efforts in the region rather than species. Substantial work is still needed to map bryophyte distributions accurately in the province. Furthermore, increased sampling and the consultation of herbarium specimens will be required to fully understand the distribution and microhabitat preferences of bryophytes throughout North America. Efforts should be made in boreal feather moss forests, which may be defined as "bryo-diversity hotspots" in view of the occurrences of uncommon, infrequent, and rare bryophyte species and, therefore, require particular conservation attention.

\section{Acknowledgements}

Funding for this study was provided by fellowships from the Fonds de Recherche du Québec-Nature et Technologies, the Natural Sciences and Engineering Research Council of Canada, and the University du Québec en Abitibi-Témiscamingue. We thank Philippe Heine and Flora Joubier for their help in collecting bryophyte samples. We also sincerely thank the Editorin-Chief Dwayne Lepitzki, the Associate Editor Jeff Saarela, and the reviewers of our paper, including Jennifer Doubt, for the constructive comments that led to this improved version of our paper.

\section{Literature Cited}

Barbé, M., N. J. Fenton, and Y. Bergeron. 2016. So close and yet so far away: long-distance dispersal events govern bryophyte metacommunity reassembly. Journal of Ecology 104: 1707-1719. https://doi.org/10.1111/1365-2745.12637

Barbé, M., N. J. Fenton, and Y. Bergeron. 2017. Are postfire residual forest patches refugia for boreal bryophyte species? Implications for ecosystem based management and conservation. Biodiversity and Conservation 26: 943-965. https://doi.org/10.1007/s10531-016-1281-9

Bergeron, Y., S. Gauthier, M. Flannigan, and V. Kafka. 2004. Fire regimes at the transition between mixedwood and coniferous boreal forest in northwestern Quebec. Ecology 85: 1916-1932. https://doi.org/10.1890/02-0716

Bisbee, K. E., S. T. Gower, J. M. Norman, and E. V. Nordheim. 2001. Environmental controls on ground cover species composition and productivity in a boreal black spruce forest. Oecologia 129: 261-270. https://doi.org/10.1007/ s004420100719

Caners, R. T, S. E. Macdonald, and R. J. Belland. 2013. Linking the biological traits of boreal bryophytes to forest habitat change after partial harvesting. Forest Ecology and Management 303: 184-194. https://doi.org/10.1016/j.fore co.2013.04.019

CNALH (Consortium of North American Lichen Herbaria). 2017. Accessed 30 June 2017. http://bryophyteport al.org/portal/. 
Crawford, R. M. M., C. E. Jeffree, and W. G. Rees. 2003. Paludification and forest retreat in northern oceanic environment. Annals of Botany 91: 213-226. https://doi.org $/ 10.1093 / \mathrm{aob} / \mathrm{mcf} 185$

Crum, H. A., and L. E. Anderson. 1981. Mosses of Eastern North America. Volumes 1 and 2. Columbia University Press, New York, New York, USA.

Dynesius, M., and K. Hylander. 2007. Resilience of bryophyte communities to clear-cutting of boreal stream-side forests. Biological Conservation 135: 423-434. https://doi .org/10.1016/j.biocon.2006.10.010

Environment Canada. 2017. Temperature and precipitation graph for 1981 to 2010 Canadian climate normals: Lebelsur-Quévillon. Environment Canada, Ottawa, Ontario, Canada. Accessed 1 February 2016. https://tinyurl.com/y87 $\operatorname{cec} 7 \mathrm{j}$.

Faubert, J. 2007. Catalogue des bryophytes du Québec et du Labrador. Provancheria 30. Mémoire de l'Herbier LouisMarie, Université Laval, Québec, Quebec, Canada.

Faubert, J. 2012-2014. Flore des Bryophytes du QuébecLabrador. Volumes 1, 2, and 3. Société québécoise de bryologie, Saint-Valérien, Quebec, Canada.

Faubert, J., D. F. Bastien, M. Lapointe, et C. Roy. 2012. Cinq hépatiques nouvelles pour le Québec. Carnets de bryologie 2: 12-16.

Faubert, J., et J. Gagnon. 2013. Bryophytes nouvelles pour le Québec. Carnets de bryologie 3: 28-38.

Faubert, J., S. Leclerc, A. Lavoie, M. Lapointe, S. Nadeau, M. Lamond, et collaborateurs. 2014+. Base de données des bryophytes du Québec-Labrador (BRYOQUEL). Société québécoise de bryologie, Saint-Valérien-de-Rimouski, Quebec, Canada. Accessed 2 March 2016. http://societe quebecoisedebryologie.org.

Faubert, J., B. Tardif, et M. Lapointe. 2010. Les bryophytes rares du Québec. Espèces prioritaires pour la conservation. Working paper. Centre de données sur le patrimoine naturel du Québec, Direction du patrimoine écologique et des parcs, Ministère du Développement durable, de l'Environnement et des Parcs, Gouvernement du Québec, Québec, Quebec, Canada.

Fenton, N. J., and K. A. Frego. 2005. Bryophyte (moss and liverwort) conservation under remnant canopy in managed forests. Biological Conservation 122: 417-430. https://doi .org/10.1016/j.biocon.2004.09.003

Fenton, N. J., N. Lecomte, S. Légaré, and Y. Bergeron. 2005. Paludification in black spruce (Picea mariana) forests of eastern Canada: potential factors and management implications. Forest Ecology and Management 213: 151-159. https://doi.org/10.1016/j.foreco.2005.03.017

Flora of North America Editorial Committee. 2007. Flora of North America, North of Mexico (Volume 27), Bryophytes: Moss, Part 1. Oxford University Press, Oxford, United Kingdom.

Gauthier, R. 2011. Le genre Tetrodontium (Tetraphidaceae, Musci) au Québec. Carnet de bryologie 1: 10-14.

Grondin, P. 1996. Écologie forestière. Pages 133-279 in Manuel de foresterie. Edited by J. A. Bérard and M. Côté. Presses de l'Université Laval, Québec, Quebec, Canada.

Hylander, K., M. Dynesius, B. G. Jonsson, and C. Nilsson. 2005. Substrate form determines the fate of bryophytes in riparian buffer strips. Ecological Applications 15: 674-688. https://doi.org/10.1890/04-0570

Ireland, R. R. 1982. Moss Flora of the Maritime Provinces. National Museum of Natural Sciences of Canada, Ottawa, Ontario, Canada.

Ireland, R. R., and L. M. Ley. 1992. Atlas of Ontario Mosses. Canadian Museum of Nature, Ottawa, Ontario, Canada.

Ley, L. M., and J. M. Crowe. 1999. An enthusiasts' guide to the liverworts and hornworts of Ontario. Lakehead University, Thunder Bay, Ontario, Canada.

Moisan, C., et S. Pellerin. 2011. Présence de la céphalozie des marais (Cephalozia macrostachya Kaal., Cephaloziaceae, Marchantiophyta) au Québec. Carnet de bryologie 1: 2325.

Newmaster, S. G., R. J. Belland, A. Arsenault, D. H. Vitt, and T. R. Stephens. 2005. The ones we left behind: comparing plot sampling and floristic habitat sampling for estimating bryophyte biodiversity. Diversity and Distributions 11: 57-72. https://doi.org/10.1111/j.1366-9516.2005 $.00123 . \mathrm{x}$

Payette, S., et A. Bouchard. 2001. Le contexte physiographique et biogéographique. Pages 9-38 in Écologie des tourbières du Québec-Labrador. Edited by $\mathrm{S}$. Payette and L. Rochefort. Les presses de l'Université Laval, Québec, Quebec, Canada.

Proctor, M. C. F. 2011. Climatic responses and limits of bryophyte: comparisons and contrasts with vascular plants. Pages 35-54 in Bryophyte Ecology and Climate Change. Edited by Z. Tuba, N. G. Slack, and L. R. Stark. Cambridge University Press, New York, New York, USA.

Saucier, J. P., P. Grondin, A. Robitaille, J. Gosselin, C. Morneau, P. J. H. Richard, J. Brisson, L. Sirois, A. Leduc, H. Morin, E. Thiffaut, S. Gauthier, C. Lavoie, et S. Payette. 2009. Écologie forestière. Pages 165-316 in Manuel de foresterie (2nd edition). Edited by Ordre des ingénieurs forestiers du Québec. Éditions Multimondes, Boisbriand, Quebec, Canada.

Schuster, R. M. 1966-1992. The Hepaticae and Anthocerotae of North America (Volume 1 to 6). Columbia University Press, New York, New York, USA.

Simard, M., N. Lecomte, Y. Bergeron, P. Y. Bernier, and D. Paré. 2007. Forest productivity decline caused by successional paludification of boreal soils. Ecological Applications 17: 1617-1637. http://doi.org/10.1890/06-1795.1

SOPFEU (Société de protection des forêts contre le feu). 2011. Digital map of the fires in Quebec from 1994 to 2003. f1094-3003-regecol.2 Geo83-P. SOPFEU, Val d'Or, Quebec, Canada.

Turetsky, M. R., B. Bond-Lamberty, E. Euskirchen, J. Talbot, S. Frolking, A. D. McGuire, and E.-S. Tuittila. 2012. The resilience and functional role of moss in boreal and arctic ecosystems. New Phytologist 196: 49-67. https://doi /org/10.1111/j.1469-8137.2012.04254.x

Vincent, J. S., et L. Hardy. 1977. L'évolution et l'extinction des lacs glaciaires Barlow et Ojibway en territoire Québécois. Géographie physique et Quaternaire 31: 357-372.

Received 16 January 2017

Accepted 5 September 2017

\section{Supplementary Material:}

APPENDIX S1. Number of plots where bryophyte taxa were found in residual forest patches and burned areas in boreal Black Spruce-feather moss forest in the southern portion of the Nord-du-Québec administrative region, western Quebec, Canada. 